Ushikoshi, W.S.' ; Gonçalves, S.' '; Ferreira, C.B. '; Bars, R. '; Calvo, D.B. ${ }^{1}$

\section{7 - Diagnóstico das paralisias flácidas. Relato de três casos}

1- Faculdade de Medicina Veterinária da Universidade de Santo Amaro, São Paulo-SP

O presente trabalho descreve três casos de paralisia flácida com preservação de dor profunda, sendo dois com diagnóstico presuntivo de polirradiculoneurite e um de paralisia por carrapato. $\mathrm{O}$ caso 1 é de um cão, Rottweiler, fêmea, de 4 meses de idade histórico de dificuldade locomotora e posterior tetraplegia há 20 dias. No início dos sintomas apresentava ixodidiose e foi tratada posteriormente com anticarrapaticida e prednisona $(0,5 \mathrm{mg} / \mathrm{kg}) \mathrm{sem}$ melhora do quadro. Proprietário negava possibilidade de ingestão de alimentos putrefados ou carcaças. Ao exame físico apresentava tetraplegia, com ausência dos reflexos medulares e preservaçào da sensibilidade profunda. Foi tratada com prednisona $(2 \mathrm{mg} / \mathrm{kg}$, a cada 24 horas $)$ e ampicilina e marcado reavaliaçòes semanais. Na primeira semana houve melhora do quadro neurológico com retorno dos reflexos medulares e discreta atividade motora voluntária. $\mathrm{O}$ tratamento foi mantido nas duas semanas subseqüentes quando o animal readquiriu capacidade de deambulação. No caso 2 , um cào, sem definiçào racial, macho, de 9 anos de idade, foi atendido com histórico de tetraparesia que se iniciou em membros torácicos e evoluíram para os membros pélvicos em 48 horas. Proprietário referia impotência funcional de membro torácico na semana anterior tratada por colega com antiinflamatório e melhora do quadro. Negava acesso à rua ou possibilidade de ingestão de alimentos putrefados. Ao exame físico foi observada otite bacteriana e, além da tetraparesia, diminuição dos reflexos medulares c do reflexo palpebral, mas não foram encontrados carrapatos. $\mathrm{O}$ animal foi entào tratado com prednisona ( $2 \mathrm{mg} / \mathrm{kg}$, a cada 24 horas), cefalexina ( $25 \mathrm{mg} / \mathrm{kg}$, a cada 12 horas) e pomada ótica tópica. Após 24 horas, referia retorno da atividade motora, porém com moderada ataxia sendo mantido o tratamento por mais 14 dias até a total recuperação. $\mathrm{O}$ caso 3 é de um canino, Fila Brasileiro, macho, com paralisia de membros pélvicos que evoluíram para os membros torácicos em 48 horas. Ao exame físico foram encontrados carrapatos na orelha externa e, ao exame neurológico, paresia de membros torácicos, paralisia de membros pélvicos com diminuição dos reflexos medulares. Os carrapatos foram retirados e realizado aplicação de carrapaticida tópico e marcado retornos para reavaliação. Nos retornos proprietário negava melhora, porém persistia a ixodidiose. Foi recomendada desinfecção do ambiente e dos contactantes e medicado com prednisona $(2 \mathrm{mg} / \mathrm{kg}$, a cada 12 horas) em face da impaciência do proprietário e na tentativa de descartar polirradiculoneurite, sem resultado. Foi aplicado entào ivermectina (200microgramas $/ \mathrm{kg}$, subcutâneo), iniciado esquema de redução da prednisona e orientação do proprietário quanto a possível causa serem os carrapatos. Após 6 dias do adequado controle da ixodidiose, o animal apresentou melhora clínica e após 14 dias retorno da atividade motora e deambulaçào. O diagnóstico das neuropatias periféricas e doenças da junção neuromuscular são um desafio na clinica veterinária e, entre elas, incluem-se o botulismo, a paralisia por carrapato e a polirradiculoneurite. Estas doenças podem apresentar características clínicas comuns de tetraparesias ou tetraplegias, de evolução aguda, geralmente ascendente, mas com preservação da dor profunda. A polirradiculoneurite foi suspeitada nos casos $1 \mathrm{e} 2$ devido a impossibilidade de ingestào de toxina botulínica e a ausência de carrapatos ou melhora adequada após a sua retirada (caso 1). O uso de corticosteróides no seu tratamento é controverso, mas como há indícios de ser uma doença imunomediada pode ser indicado e, muitas vezes, a resposta é rápida (caso 2). Já no caso 3 , como nào havia possibilidade de ingestão de toxina botulínica, a nào resposta aos corticosteróides e a melhora clínica após a retirada dos carrapatos, sugere um diagnóstico de paralisia por carrapato. 